\title{
JUURNAL.RU
}

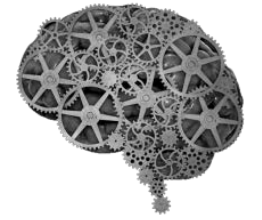

COMPANY GROUP "INTELLEKT"

\author{
Титова О.А. ${ }^{1}$, Титов А.В. ${ }^{2}$ \\ ${ }^{1}$ Государственный институт искусств и культурь \\ ${ }^{2}$ МОУ Белгородского района Белгородской области «Северная СОШ №1» \\ Белгород, Россия
}

doi: 10.18411/lj2016-6-5-05

\section{Педагогические подходы в обучении игре на фортепиано студентов- немузыкантов вузов культуры и искусств}

В статье раскрывается проблема использования в процессе обучения игре на фортепиано компетентностного, андрагогического, личностно ориентированного, культурологического и аксиологического подходов; обоснована и раскрыта эффективность их интегративного использования для реализации стратегической цели профессионального социокультурного образования - повышения его качества.

Ключевые слова: компетентностный подход, фортепианная компетентность, фортепианная компетенция, андрагогический подход, индивидуализация обучения, личностно ориентированный подход, культурологический подход, аксиологический подход, интегративность.

Предмет «Фортепиано», входящий в общепрофессиональный цикл дисциплин, изучаемых студентами-немузыкантами вузов культуры и искусств, вместе с гуманитарным, социальным и экономическим циклами учебного плана подготовки способствует формированию музыкального вкуса и музыкальной культуры будущих специалистов. Так, у студентов-звукорежиссёров, получающих образованиепо специальности 070703.65 «Звукорежиссура культурно-массовых представлений и концертных программ», формирование музыкального вкуса и музыкальной культуры происходит и через освоение 
исполнительских знаний, умений и навыков игры на фортепиано. Согласно «Федеральному государственному образовательному стандарту высшего и среднего профессионального образования» для социально-культурной сферы деятельности востребованы специалисты-звукорежиссёры, обладающие широким культурным кругозором, развитым творческим мышлением, наличием общекультурных и профессиональных компетенций.

Реалии сегодняшнего дня, в котором ведут учебно-воспитательную деятельность преподаватели общеобразовательных школ и вузов и получают образование студенты, сложны и противоречивы. Российское общество втянуто в пучину глобального мирового кризиса, охватившего не только социальные, производственные, экономические и другие сферы, но и самого человека - его сознание, духовность, чувства, поведение. «Деиндивидуализация и дегуманизация личности, предельный рационализм и нездоровый прагматизм мышления, утрата нравственных ориентиров и чувства принадлежности к своей стране, распространение ассоциальных моделей поведения, дезадаптация детей, молодежи и взрослых - это далеко не полный перечень негативных явлений, указывающий на снижение качества человеческой жизни в процессе расчеловечивания «собственно человеческого в человеке»[1, С. 44 ].

Особая роль в устранении экономического, гуманитарного, духовнонравственного кризиса в современной российской действительности принадлежит социально-культурному образованию, так как оно непосредственно связано с подготовкой специалистов для сферы культуры и искусств - основных субъектов социально-культурных преобразований, которым предстоит выполнить «историческую миссию формирования активной личности как высшей ценности общества» [2, С. 2 ]. Специалисты сферы социально-культурной деятельности в своей работе реализуют принципы творчества и гуманизма, осознания универсальных духовно-нравственных и эстетических ценностей, величие национальных и мировых произведений культуры и искусства. Все это обусловливает необходимость перехода от 
знаниевой $к$ деятельностной парадигме социокультурного образования, ориентированной на подготовку специалиста, способного к качественному изменению социально-культурной сферы на ценностном уровне.

Сегодняшние требования к специалисту социально-культурной сферы базируются на современных требованиях к образованию. «Система образования направлена, - отмечает В.Г. Миронов, - на формирование высокоинтеллектуальной, духовно богатой, толерантной, профессиональномобильной личности, владеющей общечеловеческими нормами нравственности и культуры, здоровья и способной обеспечить устойчивое повышение качества собственной жизни и общества в целом[3, С. 73 ] .

Среди будущих специалистов социально-культурной сферы особую нишу занимают специалисты-немузыканты, обучающиеся игре на фортепиано. В области музыкально-исполнительских дисциплин эти специалисты должны многое знать и многим владеть, потому что музыка обладает особой силой чудодейственного, чарующего воздействия на умы и сердца людей, на их духовность и возвышенное стремление стать добрее, честнее, отзывчивее, научиться понимать и ценить прекрасное. Поэтому специалист социокультурной сферы, владеющий музыкально-исполнительской дисциплиной, должен уметь исполнить грамотно, технично точно, художественно-выразительно сольную инструментальную программу; аккомпанировать певцу-солисту, вокалисту или инструментальному ансамблю, хору; петь под собственный аккомпанемент; читать с листа и транспонировать; подбирать по слуху; составить словесный комментарий к исполняемым произведениям; владеть навыками самостоятельной творческой работы над музыкально-исполнительским репертуаром, необходимым ему как специалисту немузыкальных профессий, обучающемуся игре на фортепиано для будущей социально-культурной деятельности. Эти же высокие требования предъявляются и к студентам немузыкальных специальностей без начальной музыкальной подготовки в вузах 
(бакалавриат) культуры и искусств, если в учебные программы их подготовки включено обучение основам фортепианного искусства.

В наше время контингент поступающих в вузы и колледжи культуры и искусств на немузыкальные специальности включает в себя все более возрастающие группы абитуриентов, не имеющих начальной музыкальной подготовки. Все это и создает в вузах искусств и культуры сложную педагогическую ситуацию и ставит перед преподавателями фортепиано целый ряд проблем. В первую очередь это проблемы необходимости осознания и понимания психологических, педагогических, психолого-педагогических, культурологических и социологических особенностей тех юношей и девушек, которые заполнили учебные аудитории. Это люди, родившиеся и выросшие в 90-ые годы XX и в первое десятилетие XXI в. А они - представители поколения постиндустриального, информационного этапа развития человеческой цивилизации, постсоветского периода истории нашей страны. Они отличаются от предшествующих поколений студентов, однако в их обучении и воспитании это почти не учитывается. Нельзя забывать и о том, что эти студенты пришли учиться в вузы культуры и искусств с уже стихийно, спонтанно сложившимся музыкальным вкусом и музыкальной культурой, зачастую деформированными современной поп-музыкой, рок-музыкой, низкопробным шоу-бизнесом, оглушительным ревом и громом дискотек. У них за плечами определенный накопленный жизненный и музыкальный опыт. Их музыкальный вкус и музыкальную культуру чаще всего приходится либо корректировать, либо вовсе формировать заново на основе программного материала народной, эстрадной и классической фортепианной музыки. Это сложнейшая и ответственная задача, если учесть, что музыкальное образование является важнейшей составляющей частью культурного образования, обладающего интегративным свойством, объединяющим все остальные сферы художественно-творческого и нравственно-эстетического становления настоящего профессионала социально- 
культурной деятельности, востребованного временем и отвечающего социальному заказу общества и государства по подготовке этих специалистов.

Чтобы готовить востребованных специалистов, в системе их подготовки надо разрешить целый ряд противоречий. В рамках статьи мы раскроем лишь одно из них: преобладание в фортепианном образовательном процессе традиционного музыкального педагогического подхода и фактическое отсутствие интегративного, комплексного использования подходов: компетентностного, андрагогического, личностно ориентированного, культурологического, аксиологического. Методологическое обоснование использования их в обучении игре на фортепиано таково:

Компетентностный подход в ФГОС рассматривается как стратегическое направление развития всей системы российского образования. Его концепция непрерывно развивается и совершенствуется ведущими теоретиками педагогики и психологии (Д.С. Ермаков, Э.Ф. Зеер, И.А. Зимняя, В.В. Краевский, Р.В, Мухаметзянова, А.М. Новиков, В.В. Сериков, А.В. Хуторской и др). Интересно отметить и то, что авторы проекта «Профессиональный стандарт педагогической деятельности» (Я.И. Кузьмин, В.Л. Матросов, В.Д. Шадриков) оформили первый опыт создания этого стандарта с позиций компетентностного подхода. Они опирались на такую его формулировку: «Компетентностный подход - это подход, акцентирующий внимание на результате образования, причем в качестве результата рассматривается не сумма усвоенной информации, а способность человека действовать в различных проблемных ситуациях»[4, C. 21]. Именно это качество и должно быть присуще специалистам социокультурной деятельности. Поэтому музыкальное образование, в том числе и обучение студентов-немузыкантов основам игре на фортепиано, основано, в первую очередь, на компетентностном подходе. Компетентностный подход в обучении игре на фортепиано нацелен на повышение качества образования, «ориентирован на цели-векторы: обучаемость, самоопределение (самодетерминация), самоактуализация, социализация и развитие 
индивидуальности», на реализацию в фортепианном образовательном процессе «его метаконструкторов: компетентностей, компетенций, метакачеств» [5, С. 2]. Фортепианная компетентность - характеристика музыкального кругозора обучающегося, его фортепианного мышления, музыкальных способностей, музыкального вкуса, музыкальной культуры, пианистических знаний, умений, навыков и владения способами музыкальной деятельности. Фортепианная компетенция - это характеристика личности, проявляемая в игре на фортепиано, это заданные педагогические, социальные и профессиональные требования к фортепианной подготовке специалиста, необходимые для его будущей профессиональной деятельности. Из этого можно сделать вывод, что фортепианная компетентность - это сложная, интегральная характеристика, состоящая из комплекса фортепианных компетенций, содержание которых определяется целями, задачами и характером фортепианной деятельности. Компетентность и компетенции вбирают в себя как когнитивную и операционально-технологические составляющие, так и мотивационную, этическую, социальную и поведенческую. Следовательно, понятие «фортепианная компетентность» включает результат обучения (знания и умения), систему ценностных ориентаций, профессионально важные личностные, музыкальные и социально-культурные качества специалиста. (Понятие «компетентность» трактуется как «основывающееся на знаниях, интеллектуально и личностно-обусловленная социально-профессиональная жизнедеятельность человека) [6, С. 11].

Использование компетентностного подхода в музыкальном образовании будущего специалиста социально-культурной деятельности, изучающего игру на фортепиано, означает формирование его фортепианной компетентности.

Методологической основой обучения игре на фортепиано студентовнемузыкантов без начальной музыкальной подготовки является и андрагогический подход (Л.Г. Брылева, С.Г. Вершловский, В.В. Горшкова, В.П. Зинченко, А.С. Запесоцкий, С.И. Змеев, А.П. Марков, В.С. Степин и др). 
Андрагогическая теория обучения студентов основана на глубоких и прочных знаниях психолого-педагогических особенностей воспитания, обучения и развития взрослых. Осмысление и обоснование использования андрагогического подхода в фортепианном обучении студентов немузыкальных специальностей без начальной музыкальной подготовки в вузах культуры и искусств должно исходить из учета ряда факторов (личностные качества студента, жизненный опыт, музыкальные способности, наличие проблем, решаемых образовательными средствами обучения игре на фортепиано, ориентация на необходимость и полезность приобретенных пианистических знаний, умений и навыков в личной и будущей профессиональной деятельности и т.д.). Все перечисленное обязывает преподавателя фортепиано не только владеть содержанием учебной дисциплины, но и быть консультантом, советчиком, опекуном, экспертом успехов студента в организации фортепианного образовательного процесса, реализуя в нем принципы самостоятельности, совместимости в обучении между обучающим и обучающимся, индивидуализации, системности, контекстности, актуализации результатов, элективности, развития образовательных потребностей, осознанности, учета психологических качеств и свойств студента.

Широкое использование принципа индивидуализации пронизывает весь комплекс педагогических подходов. Индивидуализация обучения игре на фортепиано - не просто форма занятия, но фактор, средство и условие его успеха. Она ярко выражена в личностно ориентированном подходе (Б.Г. Ананьев, Е.В. Бондаревская, Е.П. Сорокоумова, С.Я. Рубинштейн, И.С. Якимовская и др), в психолого-педагогических трудах (Э.Б. Абдуллин, Г.М. Коган, В.В. Медушевский и др), А.И. Исенко, Е.А. Ручьевская, Г.М. Цыпин и др - в музыкальной педагогике и в методике обучения игре на фортепиано).

Применительно к обучению игре на фортепиано в условиях использования аксиологического подхода у студентов формируются ценностные ориентации и ценностные отношения ко всем видам, формам, жанрам, стилям фортепианного 
искусства. Лишь на основе этого подхода в обучении возможно воспитание не только ценностного отношения к фортепианной музыке, но и повышение интереса к пианистическому виду искусства, фортепианным знаниям, умениям и навыкам и последующем их активном использовании в личной и профессиональной социально-культурной деятельности на уровне хорошего музыкального вкуса и высокой музыкальной культуры.

Комплексное использование педагогических подходов в процессе обучения игре на фортепиано студентов-немузыкантов вузов культуры и искусств- сложный, многогранный, но перспективный аспект решения проблемы повышения эффективности и качества фортепианного образовательного процесса. 


\section{Литература:}

1 Васильева Е.Н. «Инновационная парадигма российского социокультурного образования». /Автореф. диссерт. исслед. на соискание учен. степ. доктора пед наук. Тюмень 2007 г/. - C.2.

2 Горшкова В.В. Образование взрослых в аспекте культуры: феноменологический аспект. // Педагогика 2011, №7/. - С. 44.

3 Зеер Э.Ф. Компетентностный подход к обучению // Педагогика, 2003, № 3/. - C. 2.

4 Зимняя И.А. Ключевые компетентности как результативно-целевая основа компетентносного похода в образовании. М.: Исследовательский центр проблем качества подготовки специалистов, 2004. - С 11.

5 Ильенков Э.В. Философия и культура. М. Политиздат.1991.

6 Миронов В.Г. Инновационная направленность - фактор конкурентоспособности педвуза.// Педагогика, 2012, № 1/. - С. 73

7 Профессиональный стандарт педагогической деятельности // Под ред. Я.И. Кузьминова, Л.В. Матросова, В.Д. Шадрикова / Вестник образования, 2007, №7. - C. 21-37. 